\title{
Macro Algae: Biodiversity, Usefulness to Humans and Spatial Study for Site Selection in Oceanic Farming
}

O. Olanrewaju Sulaiman ${ }^{1},{ }^{*}$, Abdul Rashid Norlaily Binti Abdul Raship ${ }^{1}$, Ab Saman Abd Kader ${ }^{2}$, Shamila Azman ${ }^{2}$, Rosa D’Angelo $^{3}$, Adriano Madonna ${ }^{3}$ and Kong Fah Tee 4

${ }^{1}$ School of Ocean Engineering, University Malaysia Terengganu, Kuala Terengganu, Malaysia

${ }^{2}$ Marine Technology Centre, University Technology Malaysia, Skudai, Malaysia

${ }^{3}$ Department of Biology, Federico II University of Naples, Naples, Italy

${ }^{4}$ Department of Engineering Science, University of Greenwich, Chatam Maritime, UK

"Corresponding author: O. Olanrewaju Sulaiman, School of Ocean Engineering, University Malaysia Terengganu, Kuala Terengganu, Malaysia, Tel: +609668-3697; Fax: +609-6683193; E-mail: oosulaiman@gmail.com

Received date: Oct 7, 2015; Accepted date: Oct 11, 2015; Published date: Oct 20, 2015

Copyright: ( $) 2015$, Sulaiman OO, et al. This is an open-access article distributed under the terms of the Creative Commons Attribution License, which permits unrestricted use, distribution, and reproduction in any medium, provided the original author and source are credited.

\begin{abstract}
This minireview focuses on current understanding of the blue technology with special emphasis on algae products utilization. These relationships are discussed based on their economic value. The emerging antioxidant role for human health is highlight and the approach used to identify the oceanic parameters that are most suitable for the macro algae cultivation in Bidong Island, Redang Island, Perhentian Island and Setiu Wetland (Malaysia water) is reported.
\end{abstract}

Keywords: Blue economy; Oceanic farm; Seaweed; Antioxidant; Malaysia; Bidong island; Redang island; Perhentian island; Setiu wetland

\section{Introduction}

Increasing number of population, advanced technology and economics growth somehow has caused energy depletion and global climate change. It has been driving the seeking for blue-economy resource, challenges and opportunity in this new millennium [1]. The oceanic farms represent a new opportunity. Nowadays, to satisfy human needs, requires a global economy less dependent on fossil resources. So a transition onto a bio-based economy where raw materials are directly produced starting from soil and water, offers a way of energetic independence and a green economy. Many models for biomass production are based on culture of benthic marine algae. Seaweeds show a faster growth rate than land plants, and are more efficient in catching the carbon dioxide. Infact, algae are commercially cultivated for cosmetics, pharmaceuticals, nutraceuticals, and aquaculture purpose. Furthermore, they have been included in the food production of useful compounds; used as food supplement, as bio filters to remove nutrients and other pollutant from wastewaters; to record water quality, as indicators of environmental change; in space technology, and in laboratory and clinical research systems [2]. They also can be used to yield hydrogen, biodiesel and biobutanol which produce vastly superior amounts of vegetable oil, corn, sugarcane, wheat, and maize which higher productivity to compare terrestrial crops grown for same purpose [3]. The production of biodiesel via trans-esterification of algal oils and has similar properties as petrodiesel. Bio-butanol is a promising gasoline alternative that is being intensively studied while algae biofuel is relatively mature [4]. In this mini review we will summarize the astounding diversity of seaweed and their utilization, we will highlight one of the emerging value function and we will deal with all the parameters suitable for algae cultivation in many types of habitat in Malaysia such as Bidong island,
Redang island, Perhentian island and Setiu wetland. At later stage, these data may become useful when constructing this new challenge and opportunity on blue economy.

\section{Brief Characterization of the Seaweeds and their Economical Utilization}

\section{General seaweeds classification}

A first classification of seaweeds is given by their ability to absorb light for the purpose of photosynthesis. They, therefore, based on this parameter, are grouped microalgae or marine macro algae (kelp or seaweed) in red algae (or rodophytae, rodophyicae), brown algae (or pheophytae, pheophycae) and green algae (or chlorophytes, chlorophycae) (Figures 1a-c). Red algae possess pigments as phycoethrinn, phycocyanin, carotenes and xanthophylls, which give them the peculiar shade of red; brown algae possess xanthophyllis and carotenes, which gives a dark shade, absorbing the rays of blue-green; green algae possess $\mathrm{a}$ and $\mathrm{b}$ chlorophyll and the way in which these organisms accumulate reserve substances in the form of starch, suggest the existence of a phylogenetic link with land plants [5]. Algae, living in all the seas in the world, show thousands of families and species, each with different characteristics and to recognize and distinguish them from one another often requires specialized investigations [6]. A basic difference lies in the coloring given by the various pigments blended with the chlorophyll [7] and more often by the depth where they live. Chlorophytes are found, usually, in the intertidal and infralitoral zone, up to a depth of about 10 meters, as they require a bright light. They are abundant in the warm seas and scarce in the Arctic. The brown algae are mostly found in the cold waters, although the so-called fucali like Sargassum $s p$, are observed in tropical and subtropical regions. Their main diffusion is observed up to about 20 meters deep, but the larger forms can exceed $-30 \mathrm{~m}$. The rodophyites live at greater depths. They have a wide distribution, but are particularly found in temperate seas. Usually they live in low light 
waters. In the Mediterranean, there can also live up to 130 meters deep [8].

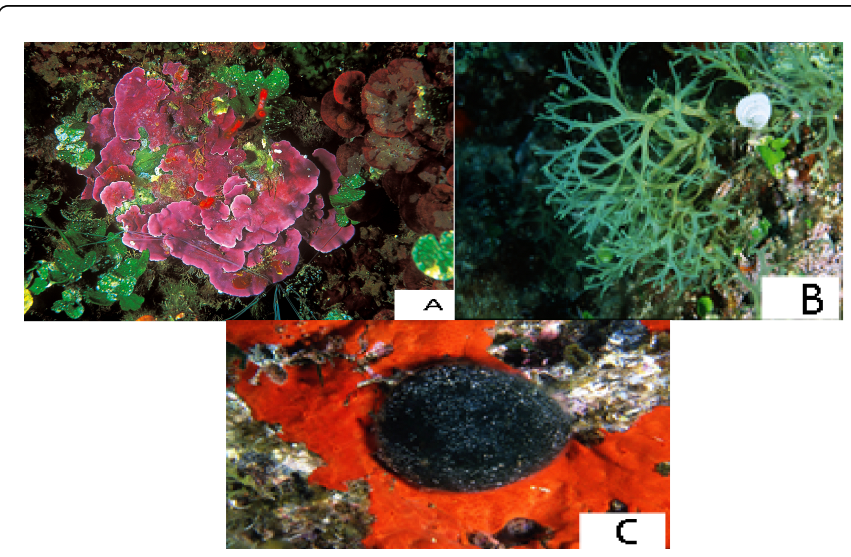

Figure 1: A: Lithophillum lichenoides, a red alga; B: Dictyota dichotoma, a brown alga; C: Codium bursa, a green alga.

\section{Algae application on blue economy}

Algae are used worldwide in several fields for research and industrial products. Studies on the biological processes of photosynthesis and ability of algal cultures to adapt to the environment allow using them to capture carbon dioxide $\left(\mathrm{CO}_{2}\right)$ emissions from fixed points, to produce clean energy, anti-cancer, anti-inflammatory, anti-viral, food, feed, cosmetics [9]. There is an increasing interest too for the extracellular transfer of electrons (EET) from organisms to receptors, in the study of the Bio-Photo Voltaic (BPV). This is a recently developed technology that exploits the fact that higher plants harvest the solar energy and metabolites to generate electric power [10]. The EET activity of the Chattonella marina, seaweed of the Raphdophyte, has been measured. Electron output by $C$. marina measured in cell suspension deriving from the water photolysis was higher than those present in biofilms at the electrode surface. Further, the suspension continued even when contact between the organisms and the electrodes was prevented by dialysis membrane, meaning the soluble electron carriers secreted by $C$. marina increase the EET process. [11]. Algae can also be a preventive tool from nuclear emergency, useful to limit the damage caused by radioactivity in the sea. By using techniques of X-ray fluorescence microprobe (XFM), there were examined the mechanisms by which the green alga Closterium moniliferum selectively captures Barium (Ba), Strontium (Sr) and $90 \mathrm{Sr}$ on intracellular Calcium (Ca), and form (Ba, $\mathrm{Sr}$ ) $\mathrm{SO}_{4}$ crystals in the vacuoles [12]. Several assays revealed a lack of selectivity in uptake and transport of $\mathrm{Sr}$ and $\mathrm{Ca}$. Strontium-90, a highly radioactive isotope, and chemically very similar to calcium, is one of the main substances dissolved in the water coming from the reactors of the nuclear power-plant in Fukushima. This compound is able to infiltrate and fixate in biological tissues (bone, muscle, blood and bone marrow in particular) and, decaying, to expose the body to high doses of ionizing radiation resulting in the development of neoplastic diseases. The half-life of the isotope is about thirty years [13]. It's assumed that it can be possible to direct seaweeds food preferences toward the strontium, increasing the amount of barium and sulphate present in contaminated water. In medical field, algae are used to repair bones and other human tissues heavily damaged, without any adverse tissue response. Unlike other plants, seaweeds do not present the vascular tissue, but they use a gelatinous substance to keep cells together. This hydrogel combination in form of alginate-gelatin and hydrohypatite, necessary to create stable 3D structures, allows living human's Mesenchymal Stem Cells (hMSCs) to be added in the bio-ink. This approach showed that, right after a 3 days in vitro culture, the cellular vitality remains high. [14]. Anyway this is at moment only an experimental trial, still far away from using the bio-printing clinically. As world energy demand continues to rise and fossil fuel resources are depleting, marine macro algae is receiving increasing attention as an attractive renewable source for producing fuels. Biomass produced by marine plant has many advantages over terrestrial plant biomass. The average photosynthetic efficiency of aquatic biomass is $6-8 \%$ which is much higher than that of terrestrial biomass (1.8-2.2\%) [15]. Furthermore, aquatic biomass presents an easy adaptability to grow in different conditions, either in fresh or marine waters, or in a wide enough range of $\mathrm{pH}$. Micro-algae have received so far more attention with respect to macro algae as agents for enhanced $\mathrm{CO}_{2}$ fixation due to their facile adaptability to grow in ponds or bioreactors [16]. Recent breakthroughs in converting carbohydrates from seaweed biomass into liquid biofuels, as the bioethanol produced through metabolic engineering, have demonstrated the applicability of seaweed biomass in this field [17]. Either kelp or seaweed could be used for solar energy conversion and biofuel production [18]. Seaweeds reproduce rapidly, and this is an important assumption in the production of biodiesel, anyway species with a high level of lipids show a lower rate of growth. Great progresses in this field have been made to identify and develop induction methods of the biosyntesis of the lipids, and to study their commercial application for the production of biodiesel [19].

\section{A new take for humans}

Algae are eukaryotic organisms capable to photosynthesis. During their life cycle all the plants, and so the kelp or seaweeds too, they frequently have to face non optimal conditions called abiotic stress. Under stress conditions, the photosynthetic apparatus isn't capable to use all the energy derived from the light. The electronic transport slows down and the excited chlorophylls can interact with the molecular oxygen, producing Reactive Oxygen Species (ROS) [20]. The algae antioxidant activity is due to their large amount of pigment, further they contain active compounds for protection from lipid peroxidation. Since the beginning of the XIX century emerged the interest for the healing properties of the algae. It's in the 1944 that, thanks to the English biochemist Tisher identified the astaxanthin as the main carotenoid responsible of the red coloring of the algae. It is exclusively synthesized by unicellular microalgae Haematococcus pluvialis. The astaxanthin shows more than just one antioxidant way of action, and can both inactivate the free radicals and neutralize the singlet and triplet oxygen. It produces an effect far superior thanks to its particular molecular structure. The mechanism of action of the astaxanthin starts with the entrapment of the free radicals at the level of their lipophilic chain, with the resulting transfer of the unpaired electron to the polar portion; this put the astaxanthin in an intermediate reactive form capable to react with other water-soluble antioxidant molecules [21]. Since then the interest for the determination of the antioxidants properties of the algal extracts is increasing always more. One of the most recent discoveries indicates that seaweeds can help in the senile dementia and the Alzheimer disease since their ability to act on the nervous system by stimulating the cognitive processes and memory. This is due to the homotaurine, a small amino-sulphate complex, isolated from several species of red algae (Grateloupia livida), with a protective effect against the DNA damage caused by the free radicals 
generated from the oxidation of the catecholamines [22]. Its great effectiveness designed it as a major drug for clinical experimentations in patients affected by Alzheimer. This drug, commercialized as Tramiprosate, has been widely studied in several clinical trial. The challenge is to demonstrate that the homotaurine is efficient as a secondary prophylaxis in patients which showing early symptoms. dant that has ever been discovered [23]. Recent studies evaluate the effects of methanol extracts with an antioxidant effect from brown algae (Sargassum muticum) against the proliferation of breast cancer cell lines [24]. The assays indicate the cytotoxic action in dosedependent manner. The apoptosis percentage of carcinogenic cells can increase from 13 to 67 by increasing the concentration of methanolic extract. The induction of apoptosis is a useful approach in cancer therapies. Researchers harvested red algae (Eucheuma cottonii), from the Northern Borneo's coastal waters, obtaining a dried extract. This powder is rich in carotenoids and antioxidants, such as phytopheophylin and phlorotannis. To test the anti-breast cancer activity of this extract, they used rats injected with breast-cancer cells LA7. A group of rats has been treated with the chemotherapeutical drug for 4 weeks, and they show a decrease of $71 \%$ of the tumor. Rats treated with the algae extract shown, instead, a decrease of $91 \%$. Furthermore the algae revealed no to be toxic on other organs, as kidney and liver [25]. A recent study, conducted on the Malaysian unicellular microalgae Isochrysis galbana and Chaetoceros calcitrans to demonstrate their high potential as a natural antioxidant resource with a high nutritional value [26]. Nutritional analyses were performed on microalgae with high antioxidant activities. For examples, I. galbana had average percentage composition of protein, carbohydrate, and lipid, as $47.9 \pm 2.5 ; 26.8 \pm 0.2 ; 14.5 \pm 1.4 \%$, respectively, while the corresponding values for $C$. calcitrans were $36.4 \pm 1.7 ; 27.4 \pm 3.0 ; 15.5$ $\pm 0.9 \%$. In addition, they contained high levels of omega- 3 PolyUnsatrated Fatty Acids (PUFA) and (omega-6 PUFA and a high composition of essential amino acids. It's interesting to note that they could be used as substitutes to replace dangerous synthetic antioxidants as well as alternative sources of substances which preserve the food quality, thus maintaining their nutritional value. Concerning human health was found that the richness of bioactive algal metabolites are involved in the regulation of the processes that control the metabolism. Different extraction methods have been used to demonstrate that brown algae have a higher phenolic content than red algae, with antioxidant, anticancer, antibacterial and antifungal properties [27]. This minireview examples ranging from laboratory studies through to clinical trials where antioxidants derived from seaweeds may provide major health benefits that warrant subsequent investigate studies and possible utilization [28].

\section{Spatial Study for Site Selection of Seaweed Oceanic Farming}

Our spatial study have been focused on element which is sea water analysis, energy value and carbon sink test for power and emission from biomass species following the methods reported in Sulaiman, [29].

Sea water analysis: The water analysis was involved mapping the biomass species and identifies the location of their growth using multiparametric analyzer Micromac (SYSTEA, Italy) using standard method. Water samples were collected during the same month from different location that is Bidong island, Setiu wetland and Perhentian island. Since several places are involved, each water sample analysis is taken at different time. The water samples are stored in dark plastic bottles and kept at the sampling no longer that six hours before filtered by hand operated vacuum pump.
Caloric energy value and carbon sink: Biomass energy extracts carbon to reduce the carbon stocks. The carbon sinks remove carbon dioxide from the atmosphere. The main natural sinks are absorption of carbon dioxide by the oceans via physicochemical and biological processes and also photosynthesis by terrestrial plants.

Calculate for power efficient and emission from biomass species: The power efficient is identify by testing biomass oil in the engine. Biomass energy reduction in the emission of atmospheric pollutants compared to conventional power sources would be investigated.

\section{Water Sample and Case Study Area}

The state of Terengganu is located on the east coast in Peninsular facing the South China Sea. Three location of sea water in Terengganu are taken as sampling site in order to identify the habitat species of algae which is Setiu wetland, Bidong island and Perhentian island. Setiu wetland is the part of Setiu River Basin and the larger SetiuChalok-Bari-Merang basin wetland complex lies in Terengganu. It is located at $05^{\circ} 40 \mathrm{~N}$ and $102^{\circ} 43^{\prime} \mathrm{E}$.

\section{Water sampling}

The water samples were takes in Setiu wetland, Bidong island and Perhentian island. The 200 meter depth is marks on the rope at the vandorn water sampler. The latitude and longitude at the location was identified using the Global Positioning System (GPS). The GPS was set up assuming 500 meter distance from the shore. The water samples are transfer into immediately bottles after takes using vandorn water sampler to prevent the distruption of surrounding. the most suitable for macro algae survive is about $29-32^{\circ} \mathrm{C}$.

\section{Setiu wetland}

Two different times are taken which is at $11.00 \mathrm{am}$ and $3.00 \mathrm{pm}$. So, four different of water samples are taken. The location of Setiu wetland

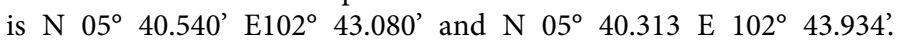
Temperature of water samples was taken a moment after exchange the samples into the bottles. The water temperature is $32^{\circ} \mathrm{C}$. This figure show the location of Setiu wetland where the water samples are taken (Figure 2).

\section{Bidong island}

Bidong island is one square kilometer in area and accessible from the coastal town of Merang. It is located at $05^{\circ} 36 \mathrm{~N}$ and $103^{\circ} 03 \mathrm{E}$. At the Bidong island also takes two times samples, in 11.00 am and 3.00 $\mathrm{pm}$. Four collected of water samples taken and the temperature were identified. It is located $05^{\circ} 36.828 \mathrm{~N}$ and $103^{\circ} 03.262 \mathrm{E}$. The water temperature is $31^{\circ} \mathrm{C}$. This figure show the location of Bidong island where the water samples are taken (Figure 3 ).

\section{Perhentian island}

Perhentian island is divided by two which is Perhentian Kecil and Perhentian Besar. The sampling site is at Perhentian Kecil with located at $05^{\circ} 51 \mathrm{~N}$ and $102^{\circ} 44 \mathrm{E}$. Two different times are taken which is at $3.00 \mathrm{pm}$ and $10.00 \mathrm{am}$ on the next day. The location of Perhentian Island is $05^{\circ} 21.26 \mathrm{~N}$ and $102^{\circ} 44.2 \mathrm{E}$ and the water temperature is $29^{\circ} \mathrm{C}$. This figure show the location of Bidong island where the water samples are taken (Figure 4). 
Citation: Sulaiman OO, Raship ARNBA, Abd Kader AS, Azman S, Angelo RD et al. (2015) Macro Algae: Biodiversity, Usefulness to Humans and Spatial Study for Site Selection in Oceanic Farming. J Biodivers Endanger Species S1: S1.003. doi:10.4172/2332-2543.S1-003

Page 4 of 6

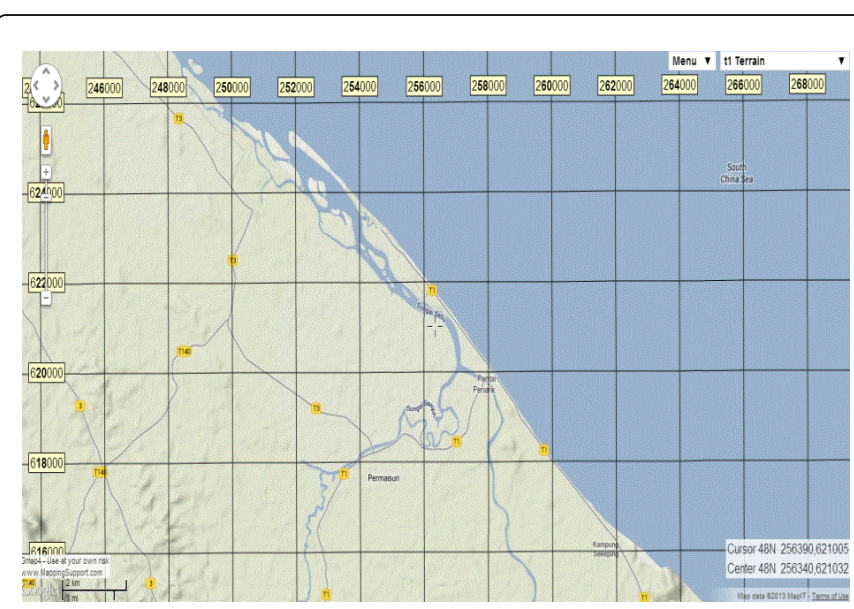

Figure 2: Setiu Wetland.

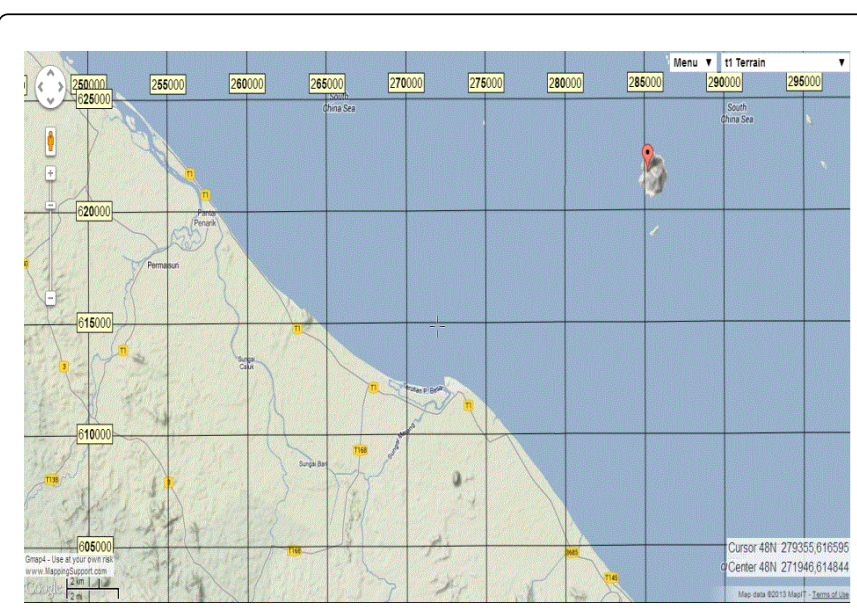

Figure 3: Bidong Island.

\section{Results}

\section{Sample collection and preservation}

Water sample are collect using vandorn water sampler and transferred to the bottle samples. Generally, at least one liter of water sample is needed. Sample volume is depending on the sampling location. The water samples are kept from heat and light to avoid pigment decomposition and bacteria infect. The location of each sampling sites are marks using GPS and the temperature of sea water is

\begin{tabular}{|c|c|c|c|c|c|}
\hline Bil & Parameter & Setiu wetland $(11.00 \mathrm{am})$ & $\begin{array}{l}\text { Setiu wetland } \\
(3.00 \mathrm{pm})\end{array}$ & Bidong (11.00am) & Bidong $(3.00 \mathrm{pm})$ \\
\hline 1 & COD & 110 & 188 & 68 & 100 \\
\hline 2 & Total nitrogen $(\mathrm{N})$ & 39 & 24 & 8 & 15 \\
\hline 3 & Total phosphate $(P)$ & 0.04 & 0.03 & 0.03 & 0.02 \\
\hline 4 & Total Phosphate (P03-4) & 0.14 & 0.09 & 0.09 & 0.06 \\
\hline
\end{tabular}

taken immediately to prevent surrounding disturbance. Hence, the water samples are place in an ice chest at temperature $1-4^{\circ} \mathrm{C}$. Table 1 shows the coordinate for Perhentian, Setiu and Bidon Highland.

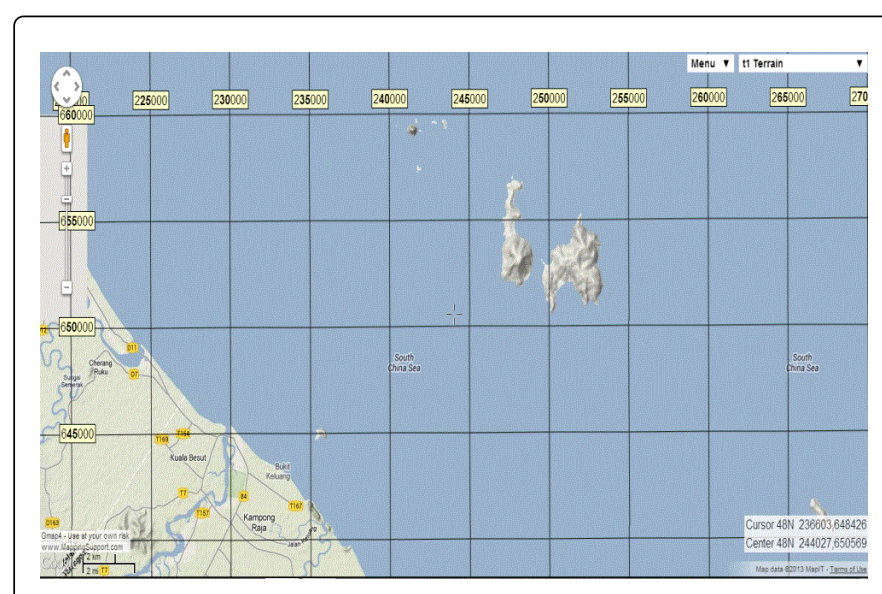

Figure 4: Perhentian Island.

Tables 2 and 3 shows respective nutrient condition of the water sample collected the sites related to Gracilaria edulis and Ulva lactuca, the more typical seaweed identified and cultured. Further, in Table 4 seaweeds habitats and their characteristics are reported.

\begin{tabular}{|l|l|l|l|}
\hline & $\begin{array}{l}\text { Perhentian } \\
\text { Island }\end{array}$ & $\begin{array}{l}\text { Bidong } \\
\text { Island }\end{array}$ & $\begin{array}{l}\text { Setiu } \\
\text { Wetland }\end{array}$ \\
\hline Latitude $\left(\mathrm{N}^{\circ}\right)$ & $05^{\circ} 52.46$ & $05^{\circ} 36.828$ & $05^{\circ} 40.540$ \\
\cline { 2 - 4 } & 52.46 & 36.828 & 40.54 \\
\hline Temperature $\left({ }^{\circ} \mathrm{C}\right)$ & 29 & 31 & 32 \\
\hline
\end{tabular}

Table 1: Location of sampling site in Setiu Wetland.

\section{Sample Laboratory Analysis}

The GF/C filter paper is set up onto the vacuum pump. The water sample is gently poured into the vacuum pump trough GF/C filter paper after switch on the vacuum pump. The sediment in water sample is ensure filtered with checking the filter paper if there is has clog or not. Experiment was set up in the laboratory to identify the nutrient contains in the seawater which suitable for types of macro algae. There are four nutrients that may identify using these experiments which is nitrate, phosphate, nitrogen and ammonia (Figures 5-7). Additional information are reported in Sulaiman et al. [30]. 
Citation: Sulaiman OO, Raship ARNBA, Abd Kader AS, Azman S, Angelo RD et al. (2015) Macro Algae: Biodiversity, Usefulness to Humans and Spatial Study for Site Selection in Oceanic Farming. J Biodivers Endanger Species S1: S1.003. doi:10.4172/2332-2543.S1-003

Page 5 of 6

\begin{tabular}{|l|l|l|l|l|l|}
\hline 5 & Ammoniacal nitrogen $(\mathrm{NH} 3-\mathrm{N})$ & 1.03 & 0.95 & 2.98 & 3.35 \\
\hline
\end{tabular}

Table 2: Location of sampling site in Bidong Island.

\begin{tabular}{|l|l|l|l|}
\hline Bil & Parameter & $\begin{array}{l}\text { Perhentian } \\
\mathbf{1 1 . 0 0} \mathbf{a m}\end{array}$ & $\begin{array}{l}\text { Perhentian } \\
\mathbf{3 . 0 0} \mathbf{~ p m}\end{array}$ \\
\hline 1 & COD & 130 & 85 \\
\hline 2 & Total nitrogen (N) & 23 & 11 \\
\hline 3 & Total phosphate (P) & 0.02 & 0.03 \\
\hline 4 & $\begin{array}{l}\text { Total Phosphate } \\
(\text { P03-4) }\end{array}$ & 0.08 & 0.1 \\
\hline 5 & $\begin{array}{l}\text { Ammoniacal nitrogen } \\
(\mathrm{NH3}-\mathrm{N})\end{array}$ & 4.26 & 2.6 \\
\hline 6 & Salinity (ppt) & 30 & 30 \\
\hline
\end{tabular}

Table 3: Location of sampling site Perhentian Island.

\begin{tabular}{|l|l|l|}
\hline Environmental parameter & G. edulis & U. lactuca \\
\hline Temperature $\left({ }^{\circ} \mathrm{C}\right)$ & $28.9 \pm 2.10$ & $28.9 \pm 2.0$ \\
\hline Salinity $(\mathrm{ppt})$ & $22.15 \pm 2.20$ & $19.5 \pm 1.50$ \\
\hline Dissolved oxygen $(\mathrm{mg} / \mathrm{L})$ & $3.58 \pm 0.05$ & $3.19 \pm 0.02$ \\
\hline $\mathrm{pH}$ & $8.43 \pm 0.20$ & $7.85 \pm 0.30$ \\
\hline Turbidity $(\mathrm{NTU})$ & $9.74 \pm 0.04$ & $8.68 \pm 0.03$ \\
\hline Ammonium $(\mathrm{mg} / \mathrm{L})$ & $1.0 \pm 0.03$ & $1.25 \pm 0.02$ \\
\hline Total nitrogen $(\mathrm{N})(\mathrm{mg} / \mathrm{L})$ & $30 \pm 1.50$ & $4.2 \pm 0.50$ \\
\hline Nitrate $(\mathrm{mg} / \mathrm{L})$ & $0.02 \pm 0.01$ & $0.23 \pm 0.02$ \\
\hline Total phosphate $(\mathrm{P})(\mathrm{mg} / \mathrm{L})$ & $0.2 \pm 0.06$ & $0.5 \pm 0.10$ \\
\hline Phosphate $(\mathrm{mg} / \mathrm{L})$ & $1.04 \pm 0.05$ & $2.22 \pm 0.04$ \\
\hline
\end{tabular}

Table 4: Seaweed habitat characteristics.

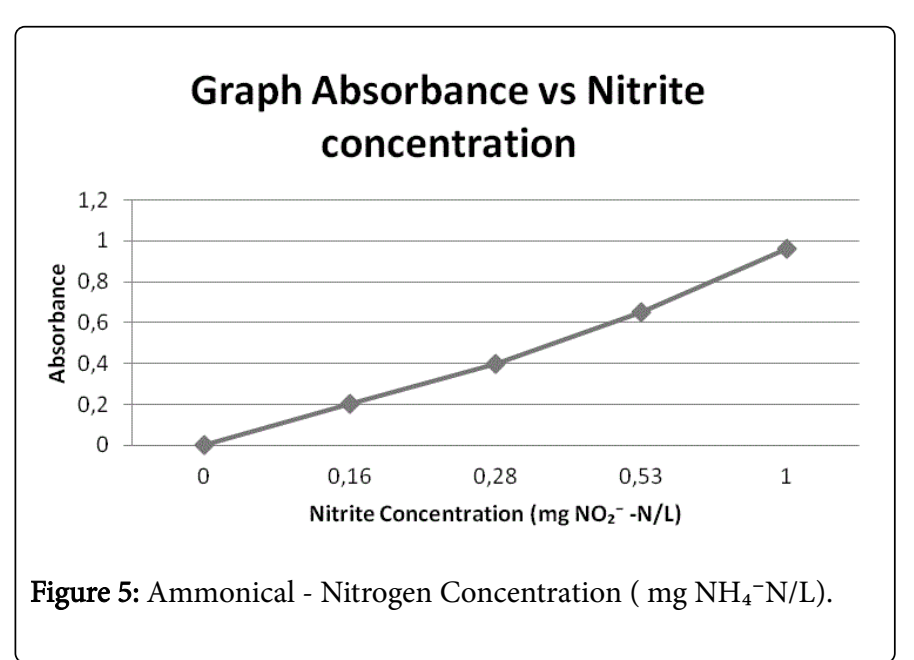

\section{Conclusion}

This mini review aims to provide an overview of the macro algae species biodiversity and their importance in the bio-economy. Furthermore, their value as emerging antioxidant treatment is reported. In conclusion, we report the current parameters for site selection of seaweed oceanic farming in many types of habitat in Malaysia such as Bidong island, Redang island, Perhentian island and Setiu wetland.

\section{Acknowledgments}

This work was supported by Newton Institutional Link Grant. The authors like to thanks Dr. Alessia Valerio for her help in the literature search.

\section{References}

1. Pearce D (2013) Blueprint 2: Greening the World Economy. Routledge, United Kingdom. 
Citation: Sulaiman OO, Raship ARNBA, Abd Kader AS, Azman S, Angelo RD et al. (2015) Macro Algae: Biodiversity, Usefulness to Humans and Spatial Study for Site Selection in Oceanic Farming. J Biodivers Endanger Species S1: S1.003. doi:10.4172/2332-2543.S1-003

Page 6 of 6

2. Van Boxtel AJB, Perez-Lopez P, Breitmayer E, Slegers PM (2015) The potential of optimized process design to advance LCA performance of algae production systems. Applied Energy 154: 1122-1127.

3. Wang C, Buchanan JS, Kliewer WR, Qian K (2015) Water-washing to reduce metals in oils extracted from Nannochloropsis algae for potential FCC feedstock. Fuel 155: 63-67.

4. Patel SKS, Kalia VC (2013) Integrative Biological Hydrogen Production: An Overview. Indian Journal of Pathology and Microbiology 53: 3-10.

5. Raven PH, Evert RF, Eichhom SE (2013) Biologia delle piante. VI edition, pp 399-410. Zanichelli. Bologna.

6. Robba L, Russell SJ, Barker GL, Brodie J (2006) Assessing the use of the mitochondrial coxl marker for use in DNA barcoding of red algae (Rhodophyta). American Journal of Botany 93: 1101-1108.

7. Morel A (1991) Light and marine photosynthesis: a spectral model with geochemical and climatological implications. Progress in Oceanography 26: 263-306.

8. Basso D (1998) Deep rhodolith distribution in the Pontian Islands, Italy: a model for the paleoecology of a temperate sea. Palaeogeography Palaeoclimatology Palaeoecology 137: 173-187.

9. Hayashi L, Bulboa C, Kradolfer P, Soriano G, Robledo D (2013) Cultivation of red seaweeds: a Latin American perspective. Journal of Applied Phycology 26: 719-727.

10. Moultrie J (2015) Understanding and classifying the role of design demonstrators in scientific exploration. Technovation 43-44: 1-16.

11. Li X, Liu T, Wang K, Waite TD (2015) Light-Induced Extracellular Electron Transport by the Marine Raphidophyte Chattonella marina. Environmental Science and technology 1392-1399.

12. Krejci MR (2012) Investigation of Biomineralization Processes Using Synchrotron X-ray Microscopy. ProQuest.

13. Krejci MR, Wasserman B, Finney L, McNulty I, Legnini D, et al. (2011) Selectivity in biomineralization of barium and strontium. Journal of Structural Biology 176: 192-202.

14. Di Bella C, Fosang A, Donati DM, Wallace GG, Choong PFM (2015) 3D Bioprinting of Cartilage for Orthopedic Surgeons: Reading between the Lines. Frontiers in Surgery 2: 39 .

15. Yokohama S, Jonouchi K, Imou K (2007) Energy Production from Marine Biomass: Fuel Cell Power Generation Driven by Methane Produced from Seaweed. World Academy of Science, Engineering and Technology 28: 320-323.

16. Aresta M, Dibenedetto A, Barberio G (2005) Utilization of macro-algae for enhanced CO2 fixation and biofuels production: development of a computing software for an LCA study. Fuel Processing Technology 86: 1679-1693.

17. Wei N, Quarterman J, Jin Y (2013) Marine macroalgae: an untapped resource for producing fuels and chemicals. Trends in Biotechnology 31 70-77.
18. Ross AB, Jones JM, Kubacki ML, Bridgeman T (2008) Classification of macroalgae as fuel and its thermochemical behaviour. Bioresource Technology 99: 6494-6504.

19. Sharma KK, Schuhmann H, Schenk PM (2012) High Lipid Induction in Microalgae for Biodiesel Production. Energies 5: 1532-1553.

20. Bianchi AR, De Maio A (2014) Synthesis and degradation of poly (ADPribose) in plants. Frontiers in Bioscience 19: 1436-1444.

21. Terao J (1989) Antioxidant activity of beta-carotene-related carotenoids in solution. Lipids 24: 659-61.

22. Caltagirone C, Ferrannini L, Marchionni N, Nappi G, Scapagnini G, et al. (2012) The potential protective effect of tramiprosate (homotaurine) against Alzheimer's disease: a review. Aging Clinical and Experimental Research 24: 580-7.

23. Dhankhar J, Kadian SS, Sharma A (2012) ASTAXANTHIN: A POTENTIAL CAROTENOID. International journal of pharma sciences and research 3: 1246-1259.

24. Namvar F, Mohamad R, Baharara J, Balanejad SZ, Fargahi F, et al. (2013) Antioxidant, Antiproliferative, and Antiangiogenesis Effects of Polyphenol-Rich Seaweed (Sargassum muticum). BioMed Research International 2013: 1-9.

25. Namvara F, Mohameda S, Farda SG, Behravane J, Mustaphab NM, et al. (2012) Polyphenol-rich seaweed (Eucheuma cottonii) extract suppresses breast tumour via hormone modulation and apoptosis induction. Food Chemistry 130: 376-382.

26. Natrah FMI, Yusoff FM, Shariff M, Abas F, Mariana NS (2007) Screening of Malaysian indigenous microalgae for antioxidant properties and nutritional value. Journal of Applied Phycology 19: 711-718.

27. Foon TS, Ai Ai L, Kuppusamy P, Yusoff MM, Govindan N (2013) Studies on in-vitro antioxidant activity of marine edible seaweeds from the east coastal region of Peninsular Malaysia using different extraction methods. Journal of Coastal Life Medicine 1: 193-198.

28. Cornish ML, Garbary DJ (2010) Antioxidants from macroalgae: potential applications in human health and nutrition. Algae 25: 155-171.

29. Kader ASA, Sulaiman OO, Wan Shamsuri WN (2013) Potential of Macro Algae for Biomass Energy Source and Green House Gas Emission Carbon Capture. Biosciences Biotechnology Research Asia 10: 653-658.

30. Sulaiman OO, Kader ASA, Wan Shamsuri WN (2013) Study of macro algae for marinebiotechnology material from large scale offshore cultivation from multiple mooring system of large aquaculture ocean floating structure. Biosciences Biotechnology Research Asia 10: 621-628.
This article was originally published in a special issue, entitled: "Usefulness of Biodiversity to Humans", Edited by Giulia Guerriero and Daniela Silvia Pace 